\title{
Testemunho de cidadãos e a prática jornalística em situações de crise
}

DOI $10.1590 / 1809-5844201417$
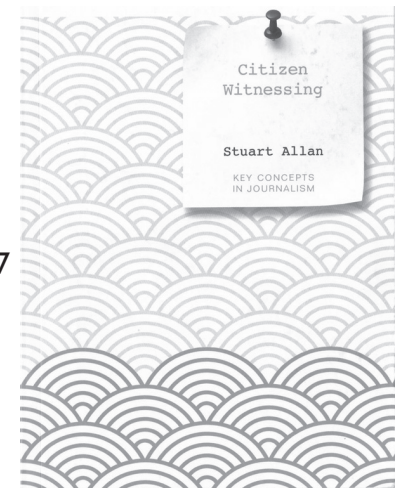

ALLAN, Stuart. Citizen witnessing: revisioning journalism in times of crisis. Cambridge: Polity Press, 2013. 253p.

$\mathrm{P}$ rofessor e pesquisador da Universidade de Bournemouth Reino Unido, Stuart Allan em seu mais recente livro intiCrisis da série Key Concepts in Journalism (Cidadão testemunhante: revendo o Jornalismo em tempos de crise, da série Conceitos chave em jornalismo, sem tradução para o português) discute a contribuição cada vez maior de cidadãos comuns no universo noticioso. Ele apresenta o conceito de "cidadão testemunhante", focando nas ações espontâneas de pessoas comuns que se sentem compelidas a participar da elaboração de notícias quando pegas em eventos de crise. Ao darem testemunho daquilo que veem, elas se envolvem em formas únicas na atividade jornalística, produzindo notícias em primeira mão por meio de relatos de testemunhas oculares, imagens em vídeo, fotografias digitais, tweets, postagens em blogs,

\footnotetext{
* Jornalista formado pela Universidade Federal do Mato Grosso do Sul e mestre em Educação pela Faculdade de Educação da Universidade Estadual de Campinas (Unicamp), Campinas-SP. E-mail: rhad@unicamp.br
} 
muitas vezes realizando uma contribuição vital para a cobertura de notícias.

Baseando-se em uma ampla gama de exemplos para ilustrar seu argumento, Allan considera o testemunho do cidadão como um serviço público, mostrando como ele pode ajudar a revigorar as responsabilidades do Jornalismo dentro das culturas democráticas.

Para o autor, a noção de "Jornalismo cidadão", que está atrelada a de "cidadão testemunhante", pode ser caracterizada como um tipo de notícia em primeira pessoa em que os indivíduos adotam temporariamente o papel de um jornalista, a fim de participar da produção de notícias, muitas vezes espontaneamente durante um momento de crise, acidente, tragédia ou desastre quando acontecem com eles presentes na cena.

Ao longo da obra, o autor discorre sobre a importância dos jornalistas estarem nos locais onde os fatos ocorreram, mesmo em situações que envolvem riscos aos profissionais. $O$ ato de testemunhar se constitui em um princípio orientador a prática investigativa. Assim, o autor minuciosamente estuda o caso do grupo de jornalistas que se deslocou a Hiroshima para cobrir os dias seguintes ao lançamento da bomba atômica ao final da Segunda Guerra Mundial.

O assassinato do presidente John F. Kennedy, gravado por Abraham Zapruder, que gerou enorme repercussão por ser o único vídeo que registrou o crime, e o espancamento de Rodney King, gravado em 1991 em Los Angeles por George Holliday, são considerados pelo autor casos em que pessoas "acidentalmente" se transformaram em jornalistas. Esses casos, que ainda não eram chamados de "Jornalismo cidadão", ocorreram antes da "era digital”, já que as câmeras filmadoras foram relativamente barateadas em meados da década de 90 e a internet ainda não havia se popularizado. O terremoto seguido de tsunami acontecido no final do ano de 2004, no sul da Ásia, foi o momento decisivo para que o "Jornalismo cidadão" se tornasse uma característica marcante na mídia. A série de notáveis relatos em primeira pessoa, imagens gravadas em vídeo através de celulares, fotos de câmeras digitais, muitas das quais publicadas online em de blogs e páginas pessoais, 
foram gerados por cidadãos nos locais atingidos pela tragédia e amplamente valorizados na cobertura jornalística. "Uma manchete de jornal, declara que o 'jornalismo cidadão' era uma reviravolta surpreendente, se não uma revolução absoluta, sendo iniciada com a tecnologia de internet".

Um dos capítulos é dedicado às notícias geradas por cidadãos testemunhantes em protestos e o papel das redes sociais. $\mathrm{O}$ autor utiliza as noções de sociedade em rede e autocomunicação de massas desenvolvidos por Manuel Castells como ponto conceitual de partida. Stuart mostra que a política, em casos de protestos articulados em redes sociais, é mais provável de ser moldada por uma consciência comum de experiências compartilhadas de uma crise, do que pela política no sentido partidário ou ativista, embora este último possa ser crucial em determinadas situações. Ele utiliza diversos casos para embasar essas ideias, como, por exemplo, os protestos na Grécia em dezembro de 2008, os protestos da etnia Uighur em Xinjiang, na China em julho de 2009 e o movimento Ocupe Wall Street em 2011. As análises realizadas pelo autor dessas ações faz com que a obra seja de leitura obrigatória para todos que desejem realizar pesquisas sobre os protestos acontecidos no Brasil em junho de 2013 e as suas relações com a mídia e as redes sociais. No entanto, apesar da relevância das redes sociais nos protestos, o autor rejeita a ideia de algo como "Revolução Facebook" ou "Insurreição Twitter".

Stuart ainda dedica um capítulo ao caso dos WikiLeaks e quando os cidadãos se transformam em denunciantes. $\mathrm{O}$ autor acredita que as garantias de serviço público proporcionado pelo Jornalismo pode ser imaginado sob o prisma da capacidade do cidadão em melhorar as culturas democráticas. Ao responder a esse novo desafio, o Jornalismo vai ser beneficiado por garantir novas oportunidades para reconectar com seu público de uma forma ao mesmo tempo mais transparente e responsável. Além de incentivar uma cultura de notícias mais aberta e inclusiva com o compromisso de um maior diálogo, reflexão e debate. Assim, a obra é de fundamental relevância para os estudantes e professores/pesquisadores de Jornalismo, sendo que a tradução para o português seria de grande importância para a comunidade acadêmica nacional. 